\title{
Fostering formal leaming in the Food Dignity project
} \section{FoodDignity}

\author{
Christine M. Porter* \\ University of Wyoming
}

Submitted April 24, 2018 / Published online July 18, 2018

Citation: Porter, C. M. (2018). Fostering formal learning in the Food Dignity project.

Journal of A griculture, Food Systems, and C ommunity D evelopment, 8(Supp. 1), 213-219.

https:/ / doi.org/ 10.5304/ jafscd.2018.08A.016

Copyright @ 2018 by the Author. Published by the Lyson Center for Civic Agriculture and Food Systems. Open access under CC BY license.

\begin{abstract}
This short essay summarizes our formal higher education work in the Food Dignity project, with some initial reflections and questions that this work raised for me, and for many of our collaborators. ${ }^{1}$ Food D ignity was a five-year action research collaboration dedicated to building community food systems that provide food security, sustainability, and equity. It was proposed and funded as an integrated program of research, extension, and education, under the U.S. D epartment of Agriculture National Institute of Food and Agriculture's (USD A NIFA) Agriculture and Food Research Initiative (AFRI) competitive grant program for food security. Five food justice community-based organizations (CBOs) and four
\end{abstract}

\footnotetext{
* Associate professor and Wyoming Excellence Chair of Community and Public Health; Food Dignity and Growing Resilience Principal Investigator; Division of Kinesiology \& Health, College of Health Sciences, University of Wyoming; 1000 East University Avenue, D epartment 3196; Laramie, WY 82071 USA; christine.porter@uwyo.edu
}

1 Unless otherwise specified, the "we" in this essay is collaborators in the Food Dignity project and the " $\mathrm{I}$ " is institutions of higher education collaborated on this project in California, Wyoming, and New York (see, for example, Porter, 2018, this issue). We had nearly US\$5 million over five years, which we extended to seven (2011-2018), to complete our proposed blend of action research. We used about $17-20 \%$ of our total effort and budget to invest in higher education programs centered around sustainable food systems (Porter \& Wechsler, 2018, this issue).

The goal of our education plan was, to quote our proposal narrative, to prepare "the next generation of graduates from multiple disciplines (e.g., anthropology, animal science, planning) to incorporate SFS [sustainable food system] priorities and principles into their work." O ur action plans for doing this included developing sustainable food

\section{Funding Disclosure}

Food Dignity (http:/ / www.fooddignity.org) was supported by Agriculture and Food Research Initiative Competitive G rant no. 2011-68004-30074 from the U.S. D epartment of Agriculture's National Institute of Food and Agriculture.

myself, the author of the essay and the Food Dignity principal investigator and project director. 
system undergraduate minors, funding several graduate students, paying for student internships in food system work, supporting communityuniversity coordination, and developing guided learning content online.

Like everything else we did together in the Food D ignity project, many of us were guided by our shared values in this education work (see Food Dignity \& Hargraves, 2018, this issue), andespecially on the academic side- were struggling to live up to them. Unlike what we have laid out in most of the other papers in this issue, we have not yet unpacked much of that struggle; we will wait to attempt that in future publications addressing what we learned during the Food Dignity project. More simply, the next sections discuss our activities within each of our formal education arenas of action. The closing section ponders a few crosscutting issues that emerged from our education work.

\section{Minors}

In 2010, as we observed in our proposal to USD A for the Food Dignity project, "only a small handful of higher education institutions offer programs in SFS [sustainable food system] studies." At the time, proposing to develop new undergraduate minors in that arena at Cornell University (Cornell) and University of Wyoming (UW) seemed nearly innovative. The only example we cited was Montana State University's Sustainable Food \& Bioenergy Systems program, which was new at that time.

Since then, sustainable food system certificate, minor, and degree programs have proliferated,

2 Current sustainable food system degree or certificate programs we identified (excluding production-centered programs, such as sustainable agriculture) are at Chatham University; College of the Atlantic; Cornell University; Flathead Valley Community College; G oshen College; G reen Mountain College; Guilford College; Kansas State University; Michigan State University; Montana State University; Montclair State University; North Carolina State University; O hio State University; Perdue University; Rio Salado College; Rutgers University; Temple University; Tompkins Cortland Community College; Tufts University; Unity College; University of California, Santa Cruz-Center for Agroecology and Sustainable Food Systems; University of California, Berkeley; University of California, Davis; University of Hawaii; University of Massachusetts; University of Michigan; University of including the two minors we developed as part of the Food D ignity project. As of April 2018 we have identified 33 U.S. institutions as having one or more of these academic programs, including 15 undergraduate, 10 graduate, and 10 minor or certificate programs on offer. ${ }^{2}$

Some of these new academic programs have been backed by "clusters" of food system faculty hires at, for example, the University of Michigan, University of Vermont, and O hio State University. The University of New Hampshire recently broke through the departmental divides that split faculty working on food systems by forming an entire interdisciplinary unit, the Department of Agriculture, Nutrition, and Food Systems. ${ }^{3}$ Also recently, the Association of Public and Land-Grant Universities (APLU) issued a report on the role of the public research university in global food security (APLU, 2017).

Thus, by 2018, the new sustainable food system minors at UW and Cornell created as part of the Food D ignity project hardly make either institution leaders of the academic pack (though Cornell's program may be one of only two that are in explicit, ongoing collaboration with food justice and security CBOs, along with Virginia Tech). We intend to share stories and lessons from developing these minors, and our attempts to develop them through community-university collaborations in each location. However, this is well beyond the scope of this summary essay, and also beyond what I could do alone. This will be the subject of future papers. (In addition to this special issue, we are planning a series of Food Dignity papers to appear

Minnesota; University of Minnesota D uluth; University of Montana-Missoula; University of New Hampshire; University of Vermont; University of Wyoming; and Virginia Tech. Penn State and University of Arizona may be planning programs. Thanks to Melvin Arthur for assistance in compiling this list. We realize it may not be complete.

3 I suspect that the W.K. Kellogg Foundation's investment in establishing sustainable food system endowed chair positions at several land grant universities, starting in 2003 at Michigan State University (https:/ / trustees.msu.edu/ decisionsnews/2003-04/ thompson.html), may have been instrumental in seeding this field of study, beyond agriculture, within U.S. higher education. This would have been further fostered from outside academia by the growth of the food movement. 
in future, regular issues of this journal.)

Here, I will say that UW secured administrative approval for a new sustainability minor, which has a food system track option, in just under two years after the beginning of the Food D ignity project. This was accomplished under the leadership of Jill Lovato (then in Environment and Natural Resources) and D eb Paulson (then in the G eography D epartment). For the establishment of a new university academic program, this is fast. D uring that design and roll-out phase, the Laramiebased food justice organization that partnered in Food Dignity, Feeding Laramie Valley (FLV), convened a group of community leaders to shape the food system track of that minor along with UW representatives. ${ }^{4}$ The first eight UW students to enroll in the minor did so in the 2013-14 academic year. Since then, the program has grown each year and become one of the most popular minors at the university, with 14 graduates as of 2017 and 41 students enrolled for the 2018-19 year. About a quarter of the students are enrolled in the food system track. UW's Haub School of Environment and Natural Resources, with leadership from Maggie Bourque, houses and advises the minor (see http:/ / www.uwyo.edu/ haub/ academics/ undergraduate-students/ sustainability.html).

Cornell embarked on a longer, more complex, and sometimes troubled journey, with at least two phases and a change in the planned home for the minor from Plant Sciences to D evelopment Sociology. The first phase was deeply entwined within Food Dignity partnerships and partners, especially the Ithaca-based CBO partnering organization, Whole Community Project. The second involved collaborations with several community-based organizations, including East New Y ork Farms! (one of the five CBO s that partnered in Food

4 From the community, these meetings included Gayle Woodsum, Lina D unning, Trish Penny, Tony Mendoza, Peggy Bell, and Rebecca Slaughter. UW associated participants were Rachael Budowle, Jessie Irish, Christine Porter, and Randa Jabbour.

${ }^{5}$ Community leaders shaping the first half of the development phase included Jemila Sequeira, D amon Brangman, Kirby Edmonds, Gayle Woodsum, Fabina Benites Colon, and Pat Brhel. Charity Hicks of D etroit also helped to facilitate a oneday retreat on this process. Cornell faculty leaders in
Dignity) and Cornell Cooperative Extension Tompkins County (CCE-TC), which had housed Whole Community Project. The Community Food Systems undergraduate minor that later emerged enrolled their first students in 2017 (see https:/ / devsoc.cals.cornell.edu/ undergraduate/ mi nor/ community-food-systems). Many faculty members at Cornell were involved in developing the minor. Community leaders associated with Whole Community Project were also deeply involved during the first phase. ${ }^{5}$ The minor coordinator, Heidi Mouillesseaux-Kunzman, expects that 23 students will have completed the capstone course in the minor by the end of 2018.

In addition, Food D ignity faculty collaborators at Ithaca College and, occasionally, some faculty at Tompkins Cortland Community College were involved or connected with the development of the minor at Cornell and have also been collaborating with people and programs at CCE-TC. The community college now offers a Sustainable Farming and Food Systems associates degree (see http:// www.tc3.edu/ catalog/ ap program.asp?dp= sustainable farming). That new degree was without any support from Food D ignity funding (though a project-funded person at Cornell, Suzanne G ervais, helped to facilitate some of the connections).

These forms of institutionalization mean sustainable food system studies in U.S. higher education will be here to stay, for at least a few generations. I consider this to be good news. At the same time, these formal higher education programs risk professionalizing community food work. This yields at least three issues. $O$ ne is robbing community leaders of jobs in the work they created in the first place. To paraphrase a question once posed by Feeding Laramie Valley's founder, $\mathrm{G}$ ayle Woodsum: are people now going to

developing the minor were Rachel Bezner-Kerr, Philip McMichael, and Scott Peters. O ther university-based participants were Heidi Mouillesseaux-Kunzman (the coordinator), Suzanne G ervais, Laurie D rinkwater, Heather Scott, Jonathan Russell-Anelli, Jennifer Wilkins, Monica Hargraves, and John Armstrong. Ithaca College also participated in some of the minor development meetings, including in relation to their own program development; people included Alicia Swords, Amy Frith, Julia Lapp, and Elan Shapiro. 
need a master's degree to get a job managing (for example) community garden programs, thus displacing community leaders who started these gardens? Another issue is the heavy capacity development investments that formally enrolled students receive, especially graduate students, with nothing remotely equivalent for community leaders already doing the work (as replicated in the Food Dignity project and discussed next). The third, and perhaps most serious, problem is professionalization de-radicalizing the activities, outcomes, and goals of such work. This includes changing the goals of such work away from justice and sovereignty and toward food-security programming. This type of programming is susceptible to development and implementation based solely on emergency and qualified need (see, for example, Boyte, 2004). In her review of a draft of this essay, Woodsum articulated the root causes of these problems, and more, as "the entrenched societal belief and institutional promotion of the idea that possession of a degree indicates possession of greater, superior, more extensive knowledge and expertise than does front-line, lived and firstperson derived/ delivered expertise."

\section{Graduate Students}

The cost of undergraduate studies is usually borne by students, sometimes subsidized by state funding for land-grant universities or by endowments at wealthy private institutions. However, graduate students normally do not pay their own tuition and do also receive a stipend, usually in exchange for teaching or research work in their department. Thus, even in grant-funded work without educational goals, principal investigators such as myself will often include funding to support graduate students, to both assist in the research and to achieve the education-related mission of academic institutions. Though the stipends often put students near poverty level, the total costs are high because they cover tuition.

In the Food Dignity project, paying for graduate students to earn their degrees and to assist with our action research and teaching represented the bulk of our education spending, at a total of US\$396,000. We fully funded five people to garner master's degrees at UW and partially funded three doctoral students (in some cases paying only a small fraction of the costs) who earned Ph.D.s at Comell or the University of California, D avis.

The "Follow the Money" paper in this issue reflects further on this investment in students, including how the students and the project benefit but how comparatively little we invested in community leaders (Porter \& Wechsler, 2018). For reflections by several of these graduate students on what they learned from community leaders and through the Food Dignity project, see their "Emotional Rigor" paper in this issue (Bradley, Gregory, Armstrong, Arthur, \& Porter, 2018).

\section{Engaged Leaming and Intemships}

When proposing a student internship component to our Food Dignity project plan, I had imagined that its purpose would be to enable students in the new minors to do engaged learning practicum work with $\mathrm{CBO}$ s, thus allowing students who would not otherwise be able to afford to do unpaid work in the summers to participate. I also thought that, at Cornell, student interns might be used for assistance with work related to Food D ignity. For both UW and Cornell, we had budgeted US $\$ 10,000 \mathrm{a}$ year (for most years) to pay for student interns, plus US\$2,000 a year for Ithaca College interns.

The program at Cornell unfolded mostly as I had expected. Unlike at UW, where I personally controlled a single account with all of UW's Food Dignity budget, Cornell's funding was allocated to departments. Some of the departments used their share of the internship funding much as I had imagined, including helping with development of the minor. However, one unit asked me to transfer its US $\$ 4,000$-per-year allocation to the Whole Community Project to enable that $\mathrm{CBO}$ to recruit and retain interns directly or otherwise direct the use of that funding to support their work.

At UW, when I discussed how to create an internship program with Woodsum at Feeding Laramie Valley, she pointed out that if her organization were going to mentor the interns, then it would make more sense for her organization to recruit them and to manage the funds. Thus, I moved $90 \%$ of the internship money to that CBO's budget. FLV developed a rich and extensive community-led internship program with 
those limited funds, which it has sustained and radically expanded since then, including by leveraging AmeriCorps VISTA opportunities. I moved the remaining US\$1,000 to the budget of the other Wyoming-based CBO partnering in Food Dignity, Blue Mountain Associates, to assist with the Tribal farmers market it founded.

Ithaca College did not have a subaward in the Food Dignity grant, and CCE-TC managed the college's small annual budget for interns. In addition, the extension office had a little additional funding to pay community-based leaders and mentors who accepted student interns. The faculty leading that effort at Ithaca College reflect deeply on their struggles and successes in striving for community-campus collaborations for food justice in this issue (Swords, Frith, \& Lapp, 2018). They outline both the struggles and the unexpected benefits of coordinating internships. Their work led to improved collaboration between departments and schools in designing and delivering curriculum related to food dignity, thus reaching more students than originally envisioned. They also developed more systematic approaches to facilitating student learning and fostering respect for community efforts by gradually increasing student engagement with community members and organizations.

\section{Community-University Coordination and More}

With a vague awareness of how much UW and Cornell would be asking of Feeding Laramie Valley and Whole Community Project at CCE-TC, in the education elements of the Food Dignity collaboration, I proposed that each of these CBO s would retain someone, as we ultimately wrote in our project proposal, to "help college/ university faculty identify in-course and summer practical sustainable community food system experiences for students." I grossly underestimated the work in this arena and proposed to allocate just US\$3,000 per year per organization to support those activities. This was not nearly enough to attract and retain someone to lead that work, although both organizations tried before integrating it into the scope of work or existing positions and activities. However, in spite of this, both organizations became deeply involved in mentoring interns directly, matching students with community mentors, co-guiding the minor development, giving guest lectures, hosting class visits and tours, and even co-teaching university courses. Overall, these are not my stories to tell, but an early analysis of FLV's experience is included in Woodsum's essay in this issue (Woodsum, 2018).

I can say that universities and colleges have often asked at least four of the five CBO s partnering in Food Dignity (with the exception of Blue Mountain Associates in Wind River, which is not near a university) to mentor student interns, speak in classrooms, and host students (and other groups) for presentations and tours. For example, East New York Farms! in Brooklyn and Dig Deep Farms in the San Francisco Bay area reported hosting hundreds of student visitors over the course of our collaboration, unrelated to their participation in the Food Dignity project.

This raises questions about the ethics of formal educational institutions-- which have a funded mission to teach--leaning on resource-strapped not-for-profit organizations to help them achieve that mission. Community co-investigators in this project helped some of the academic partners, myself included, to more fully realize and articulate that people in such organizations need to be paid for their time and expertise at rates comparable to that of the formal educators, with standard funds at educational institutions allocated for this purpose. Within the implementation of the Food Dignity project, we strived to meet this bar, but I do not believe we cleared it, and temporary grant funding is not the long-term solution in any case.

\section{Education Content Online}

We had originally proposed to create online courses in sustainable food systems, noting that, in 2010, there were few to none available. However, their subsequent proliferation made us realize a more cost-effective and impactful approach for our project might be to (a) share our formal curricular materials for courses in our new minors and (b) develop formal learning guides to some of the unique and important outputs from our action and research. We revised our plan to USD A accordingly, and these are now available on our website 
(http:/ / www.fooddignity.org).

\section{Closing, Without Conclusion}

Though global food production currently yields plenty to feed everyone today (even though our societies, collectively, do not choose to distribute it that way), much of it is produced at the expense of the ability of future generations to have enough to eat (e.g., by depleting soil, draining aquifers, and burning more carbon fuel calories as inputs than yielded as consumed food calories). O verall, community leaders and organizations have been decades ahead of U.S. higher education (with the exception of sustainable agriculture and agroecology disciplines) in tackling these issues locally, by focusing on community food security, equity, and sustainability. Since global food security is an all-hands-on-deck scale of a problem, and academic institutions can bring additional resources to the table, the increasing academic focus on this problem, including in the Food Dignity project, is largely good news.

In practice, however, higher education's entry into sustainable food system work has also been troubling, including in the Food Dignity project. These troubles include those mentioned above, such as professionalizing and deradicalizing community food system work, investing heavily in academic but not community capacity development, and asking cash-strapped CBO s to volunteer their time for doing some of the teaching work universities and colleges are paid to do.

In addition, academic lenses tend to bring technical and abstractly epistemological views to problems, whereas food justice and sovereignty-and many aspects of food security--are largely ethical and political problems. For example, the APLU report referenced above does not have a single mention of racism which, in the U.S. context, is a major factor in the history of the food system as well as the inequities within it. 6 In another personally memorable example, when Woodsum was guest-hosting a class meeting in my upper-level Food, Health, and Justice course about such systemic oppression issues, I will never forget her admonishment to me when she discovered I had not yet covered the concept of unearned privilege, even though we were two-thirds of the way through the semester.

I needed nearly seven years of educating from the community partners in the Food D ignity project to finally see and name the root cause of this array of problems as academic supremacy-- that is, the systemic and institutionalized inequities between community-based organizations and universities (see Porter \& Wechsler, 2018, in this issue). As with other forms of systemic inequity, tackling it requires short-term tactics for workarounds (in the Food Dignity project see, for example, Wechsler, 2017) and long-term strategies for institutional change. Within higher education, it requires academic allies--especially among the general ranks of tenure-track and tenured faculty--ready to acknowledge this inequity, and then to tackle it with humility, accountability and, ultimately, the sacrifice of unearned academic privilege.

\section{References}

Association of Public and Land-grant Universities [APLU]. (2017). The challenge of change: $\mathrm{H}$ arnessing university discovery, engagement, and learning to achieve food and nutrition security. Washington, D .C.: Author Retrieved from http:/ / www.aplu.org/ projects-and-initiatives/ international-programs/ challenge-of-change/ index.html Boyte, H. C. (2004). E veryday politics: Reconnecting aitizens and public life. Philadelphia, PA: University of Pennsylvania Press. Bradley, K., Gregory, M. M., Armstrong, J. A., Arthur, M. L., \& Porter, C. M. (2018). Graduate students bringing emotional rigor to the heart of community-university relations in Food Dignity. Journal of A griculture, F ood Systems, and Community D evelopment, 8(Suppl. 1), 221-236. https:/ / doi.org/ 10.5304/ jafscd.2018.08A.003

\footnotetext{
6 For reasons I attribute to my academic Food Dignity project role, I was invited to play a minor part of the authorship group for the APLU report and also a larger role as part of a small INFAS team responding with a white paper that attempted to add an anti-racism lens, from the academic Inter-institutional
}

Network for Food, Agriculture and Sustainability (INFAS). See http:/ / asi.ucdavis.edu/ networks/ infas/ a-deeperchallenge-of-change-the-role-of-land-grant-universities-inassessing-and-ending-structural-racism-in-the-us-food-system 
Hargraves, M. (2018). Introduction to the Food Dignity Values Statement. Journal of A griculture, F ood Systems, and Community D evelopment, 8(Suppl. 1), 33-35. https:/ / doi.org/ 10.5304/ jafscd.2018.08A.018

Porter, C. M. (2018). G rowing our own: Characterizing food production strategies with five U.S. community-based food justice organizations. Journal of A griculture, F ood Systems, and C ommunity D evelopment, 8(Suppl. 1), 167-185. https:// doi.org/ 10.5304/ jafscd.2018.08A.001

Porter, C. M., \& Wechsler, A. (2018). Follow the money: Resource allocation and academic supremacy among community and university partners in Food D ignity. Journal of A griculture, Food Systems, and Community D evelopment, 8(Suppl. 1), 63-82. https:/ / doi.org/ 10.5304/ jafscd.2018.08A.006

Swords, A., Frith, A., \& Lapp, J. (2018). Community-campus collaborations for food justice: Strategy, successes and challenges at a teaching-focused college. Journal of A griaulture, F ood Systems, and Community D evelopment, 8(Suppl. 1), 261-277. https:/ / doi.org/ 10.5304/ jafscd.2018.08A.009

Wechsler, A. (2017). Overcoming the Venn diagram: Learning to be a co-passionate navigator in community-based participatory research. Research for A ll, 1(1), 147-157. https:/ doi.org/ 10.18546/ RFA.01.1.12

Woodsum, G. M. (2018). Entering into a community-university collaboration: Reflections from Feeding Laramie Valley. Journal of A griaulture, Food Systems, and C ommunity D evelopment, 8(Suppl. 1), 17-22.

https:/ / doi.org/ 10.5304/ jafscd.2018.08A.017 